\title{
Influence of Hydrogen Sulfide Containing Atmospheres on the Physical and Mechanical Properties of Solid Oxide Fuel Cell Anode Materials
}

\author{
Bogdan Vasyliv' ${ }^{*}, V_{i k t o r i y a ~ P o d h u r s k a}{ }^{1}$, Orest Ostash ${ }^{1}$ and Volodymyr Vira ${ }^{2}$ \\ ${ }^{1}$ Department of Structural Fracture Mechanics of Materials, Karpenko Physico-Mechanical Institute, Ukraine \\ ${ }^{2}$ Department of Bridges and Structural Mechanics, Institute of Building and Environmental Engineering, Lviv \\ Polytechnic National University, Ukraine
}

\begin{abstract}
The solid oxide fuel cell (SOFC) may be fuelled by a variety of fuels such as natural gas, oil-derived gases and liquids, pure ammonia, and synthesis gases from coal and biomass gasification. This is possible mainly due to the high operating temperature $\left(600-1000^{\circ} \mathrm{C}\right)$ enabling the SOFC to both internally reform light hydrocarbons and electrochemically oxidize CO in addition to hydrogen. In this work, the effect of hydrogen sulfide content in a hydrogenous atmosphere on the structure, physical, and mechanical properties of SOFC anode materials has been studied. A series of specimens of porous nickel and YSZ-Ni cermet have been investigated. In order to obtain the corresponding YSZ-Ni cermet structure, specimens of the YSZ-NiO ceramics were singly reduced in a hydrogenous atmosphere (either Ar-5 vol\% $\mathrm{H}_{2}$ mixture or hydrogen of 99.99 vol\% $\mathrm{H}_{2}$ purity) for $4 \mathrm{~h}$ at $600{ }^{\circ} \mathrm{C}$ under the pressure of $0.15 \mathrm{MPa}$. A part of the specimens of each series was then aged in "hydrogen sulfide in Ar-5 vol\% $\mathrm{H}_{2}$ mixture" atmosphere for $4 \mathrm{~h}$ at $600{ }^{\circ} \mathrm{C}$. According to a test mode, the atmosphere contained 7 or $18 \mathrm{vol} \% \mathrm{H}_{2}$ S. Material microstructure and fracture surface morphology of the specimens as well as the physical and mechanical behaviors were investigated. It was revealed that the atmosphere containing up to 7 vol\% $\mathrm{H}_{2} \mathrm{~S}$ does not affect the strength and electrical conductivity of the YSZ-Ni cermet. Increased content of $\mathrm{H}_{2} \mathrm{~S}$ (18 vol\%) causes some changes in the YSZ-Ni cermet structure. A large number of completely reduced tiny nickel particles is formed. These nickel particles react with hydrogen sulfide. Sulfur is segregated on the boundaries between the zirconia and nickel phases and pores. Finally, multiple breaking of the zirconia-nickel bonds occurs that results in reduced strength of the cermet (by 39\% as compared to as-received ceramics).
\end{abstract}

Keywords

Solid oxide fuel cell, Ni-containing anode, Hydrogenous atmosphere, Hydrogen sulfide, Structural degradation

\section{Introduction}

Fuel cells are electrochemical devices that transform the chemical energy of fuel into electric energy or heat without intermediate stage of combustion. They have much higher efficiency than the energy transforming systems and a much lower level of emission than internal combustion engines. Therefore, fuel cells are ideal energy sources for transport, stationary power plants, and mobile power plants. At present, solid oxide fuel cells (SOFCs), due to their versatility (they use all known types of fuel and are only slightly affected by the purity of fuel), reveal high economic indices. The problems of degradation of the properties of individual elements of a SOFC and optimization of their structure as layered macrocomposites still remain the key problems whose solution is urgently required [1,2]. To improve the efficiency of a SOFC, it is necessary to reduce its operating temperature down to $550-600{ }^{\circ} \mathrm{C}$ and increase the

*Corresponding author: Dr. Bogdan Vasyliv, Senior Researcher, Department of Structural Fracture Mechanics of Materials, Karpenko Physico-Mechanical Institute, 5 Naukova Str., Lviv 79060, Ukraine, E-mail: frankivsk@email.ua; vasyliv@ipm.Iviv.ua

Received: July 24, 2017; Accepted: March 10, 2018; Published online: March 12, 2018

Citation: Vasyliv B, Podhurska V, Ostash O, et al. (2018) Influence of Hydrogen Sulfide Containing Atmospheres on the Physical and Mechanical Properties of Solid Oxide Fuel Cell Anode Materials. Insights Agric Technol 1(1):1-6

Copyright: (c) 2018 Vasyliv B, et al. This is an open-access article distributed under the terms of the Creative Commons Attribution License, which permits unrestricted use, distribution, and reproduction in any medium, provided the original author and source are credited. 
Citation: Vasyliv B, Podhurska V, Ostash O, et al. (2018) Influence of Hydrogen Sulfide Containing Atmospheres on the Physical and Mechanical Properties of Solid Oxide Fuel Cell Anode Materials. Insights Agric Technol 1(1):1-6

electrochemical (electrical conductivity) and mechanical (strength and a lifetime) characteristics of materials [37].

The poisoning effect of sulfur by chemisorption on $\mathrm{Ni}$-catalysts is well known [8]. It is reversible and a temperature dependent threshold exist below which no effect is observed [9]. At $700{ }^{\circ} \mathrm{C}$ the threshold is about 1 ppm, at $1000{ }^{\circ} \mathrm{C}$ the extrapolated value is of the order of $50 \mathrm{ppm}$. Poisoning by sulfur has been investigated on $\mathrm{Ni} / \mathrm{YSZ}$ cermet anodes in $\mathrm{H}_{2}+3 \% \mathrm{H}_{2} \mathrm{O}$ by several groups [10-12]. In amounts from 5 to $105 \mathrm{ppm}$ an increase of about a factor of 2 in polarization resistance has been observed. The effect at 5 ppm $\mathrm{H}_{2} \mathrm{~S}$ [11], is in contradiction with the reported limit for degradation of $\mathrm{Ni}$-catalysts performance, and no additional effect is seen applying $105 \mathrm{ppm}$. At $35 \mathrm{ppm}$ the effect was found to be reversible, and to be constant with temperature from 700 to 1000 ${ }^{\circ} \mathrm{C}$, with or without passing anodic current and equal for low-performance porous $\mathrm{Ni}$ anodes and high-performance Ni/YSZ cermets [10]. The effect was found not to be reversible at $105 \mathrm{ppm}$ [12].

Assuming that sulfur chemisorbs exclusively to the $\mathrm{Ni}$-surface, the data indicate that the Ni surface is either the location of rate limiting reactions, or that it provides a limiting species to the rate-determining reaction. It would appear that the role of the Ni-surface is fairly constant with temperature and passing of current under the given circumstances.

Considering the impedance of a full SOFC at $1000^{\circ} \mathrm{C}$, the effect of $69 \mathrm{ppm}$ sulfur is about $5 \%$ on the cell voltage, at $800{ }^{\circ} \mathrm{C} 10 \mathrm{ppm}$ sulfur causes about $2 \%$ reduction of the cell voltage [11]. These observations are partially affected by the anode usually not being the most significant limitation for well-performing SOFC. The fuel cells with $\mathrm{Ni}$ / YSZ cermet anodes have been operated with up to 2000 ppm sulfur at $950{ }^{\circ} \mathrm{C}$, maintaining output stability [10].

The aim of this work is to study the effect of hydrogen sulfide content in a hydrogenous atmosphere on the structure, physical, and mechanical properties of SOFC anode materials.

\section{Materials and Methods}

Anode materials for SOFCs have been investigated. In order to study a pure effect of an environment on nickel containing anode materials we used porous metallic $\mathrm{Ni}$ as a model material. The porosity of the material was $1.6 \%$. We also studied the behavior of the YSZ-NiO anode ceramics $\left(\mathrm{ZrO}_{2}\right.$ stabilized by $8 \mathrm{~mol} \% \mathrm{Y}_{2} \mathrm{O}_{3}$ with the addition of $50 \mathrm{wt} \% \mathrm{NiO}$ ) prepared by sintering at the temperature $1450{ }^{\circ} \mathrm{C}$. Resulting grain size of the ceramics was in the range of $1-2 \mu \mathrm{m}$, and the porosity was $29 \%$.

A series of specimens of porous metallic Ni and YSZ-
$\mathrm{NiO}$ ceramics of $1.5 \times 5 \times 25 \mathrm{~mm}$ in size were prepared. In order to obtain the corresponding YSZ-Ni cermet structure, specimens of the YSZ-NiO anode ceramics were singly reduced in hydrogenous atmosphere (either Ar-5 vol $\% \mathrm{H}_{2}$ mixture or hydrogen of 99.99 vol $\% \mathrm{H}_{2}$ purity) for $4 \mathrm{~h}$ at $600{ }^{\circ} \mathrm{C}$ under the pressure of $0.15 \mathrm{MPa}$. A part of the specimens of each series was then aged in "hydrogen sulfide in Ar-5 vol\% $\mathrm{H}_{2}$ mixture" atmosphere for $4 \mathrm{~h}$ at $600{ }^{\circ} \mathrm{C}$ under the pressure of $0.15 \mathrm{MPa}$. According to a test mode, the atmosphere contained 7 or $18 \mathrm{vol} \% \mathrm{H}_{2} \mathrm{~S}$. In order to reach the pressure of $0.15 \mathrm{MPa}$, the test chamber was degassed and filled with hydrogen sulfide of certain volume and then filled up to the pressure of $0.15 \mathrm{MPa}$ with Ar-5 vol\% $\mathrm{H}_{2}$ mixture.

The mechanical properties of the material were studied in air at $20{ }^{\circ} \mathrm{C}$ under three-point bending of beam specimens. The fracture stresses were determined from the "stress-flexure" diagrams at $\mathrm{P}=\mathrm{P}_{\max }$ for the materials by the relation

$$
\sigma_{f}=\frac{1.5 \cdot P_{\max } \cdot L}{b \cdot t^{2}}
$$

Where $\mathrm{P}_{\max }$ is the load, N, L is the span between two supporting rollers $\mathrm{mm}, \mathrm{b}$ and $\mathrm{t}$ are the specimen width and thickness, $\mathrm{mm}$. In case of a significant plasticization of material, we used for this purpose the parameter of ultimate elastic stress which corresponds to the end of a linear domain of a "stress-flexure" diagram (Figure 1).

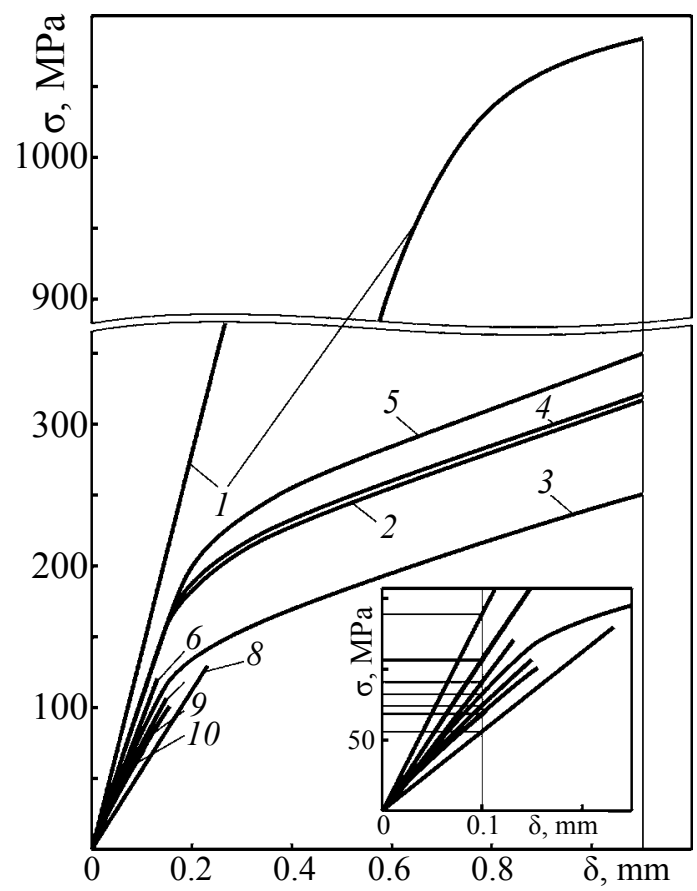

Figure 1: The "stress-flexure" diagrams for the materials in modes 1-10 (see Table 1). The magnified initial part of the graph contains horizontal lines indicating stress levels at a certain flexure, for estimation of the values of a relative stiffness $E / E_{0}$. 
Citation: Vasyliv B, Podhurska V, Ostash O, et al. (2018) Influence of Hydrogen Sulfide Containing Atmospheres on the Physical and Mechanical Properties of Solid Oxide Fuel Cell Anode Materials. Insights Agric Technol 1(1):1-6

Table 1: Influence of material treatment mode on the physical and mechanical properties.

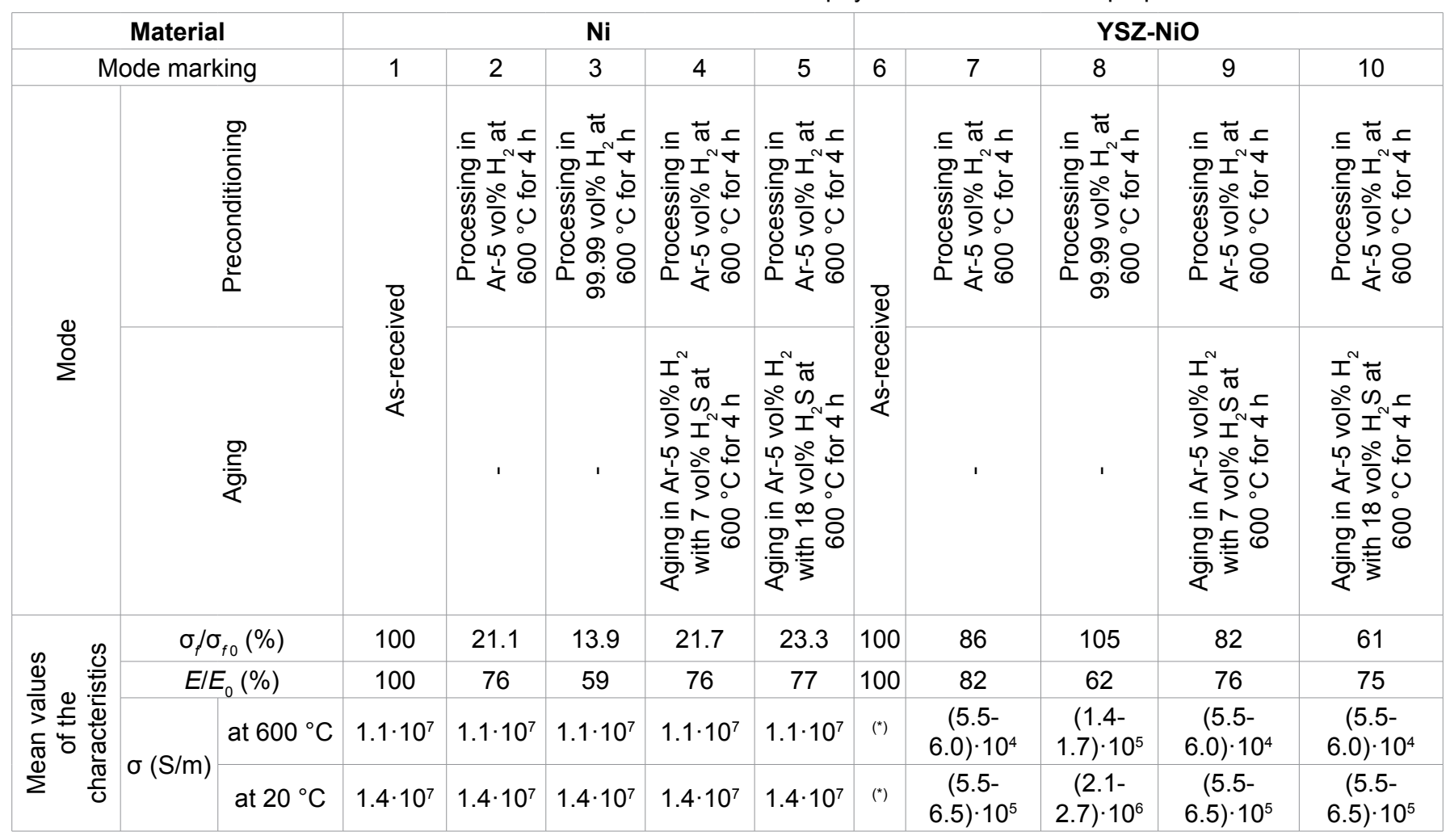

Comment: $\left({ }^{*}\right)$ Electrical conductivity is absent.

Five samples of each series were used to define the average values of the fracture stresses. The error margins were about $\pm 5 \%$ of the corresponding values.

In order to estimate material strength changes caused by the corresponding treatments, we used the relative strength parameter evaluated by the relation of $\sigma_{\mathrm{f}} / \sigma_{\mathrm{fo}}$, where $\sigma_{\mathrm{f}}$ and $\sigma_{\mathrm{f} 0}$ are the ultimate fracture stresses of material after the corresponding treatment and in the initial state.

The relative stiffness $\mathrm{E} / \mathrm{E}_{0}$, where $\mathrm{E}$ is Young's modulus, was estimated by the ratio between tangents of the slopes of linear domains of the corresponding "stress-flexure" diagrams for the material after treatment and in the initial state (see magnified initial part of the graph in Figure 1).

Based on the obtained data of the relative strength and relative stiffness of materials in modes 1-10 (Table 1), certain features of changes in their mechanical behavior were studied.

The specific electrical conductivity $\sigma$ was determined by the four-point scheme, according to the results of measurement of potential drop between given points of the specimen in two mutually perpendicular directions [13]. For the microstructural and quantitative analysis of element distribution, we applied a Carl Zeiss EVO40XVP scanning electron microscope (SEM) with an INCA Energy 350 system for energy-dispersive X-ray (EDX) microanalysis.

\section{Results and Discussion}

A significant plasticization of specimens of porous $\mathrm{Ni}$ after their exposition in hydrogenous environments at $600{ }^{\circ} \mathrm{C}$ has been revealed. The "stress-flexure" diagrams displayed drastical drop of the elasticity modulus along with the ultimate elastic stress for the material treated (Figure 1). It was stated that the higher is a content of hydrogen in a gaseous atmosphere, the lower are these characteristics and the higher is the hydrogen-assisted plasticization of nickel in general.

Based on the characteristics of relative stiffness and strength, it was revealed that hydrogen sulfide does not do any discernible influence on mechanical behavior of porous Ni (Figure 2). Neither 7 nor 18 vol $\% \mathrm{H}_{2} \mathrm{~S}$ affects plasticity and strength of the material. It can be suggested that only a content of hydrogen in a gaseous atmosphere, at the same treatment mode, i.e., holding at the temperature $600{ }^{\circ} \mathrm{C}$ and pressure $0.15 \mathrm{MPa}$ for $4 \mathrm{~h}$, affects these characteristics. The estimated values were in the ranges of 21.1-13.9\% (relative strength) and 76-59\% (relative stiffness) while a content of hydrogen in a gaseous atmosphere was changed in the range of 5-99.99 vol\% (see Table 1). A general tendency of change of these characteristics while hydrogen sulfide content increases, is indicated by the arrow along curve 1 (see Figure 2).

No changes in the electrical conductivity of porous $\mathrm{Ni}$ were found for all the treatment modes (see Table 1). 
Citation: Vasyliv B, Podhurska V, Ostash O, et al. (2018) Influence of Hydrogen Sulfide Containing Atmospheres on the Physical and Mechanical Properties of Solid Oxide Fuel Cell Anode Materials. Insights Agric Technol $1(1): 1-6$

Even a relatively high concentration of hydrogen sulfide (18 vol\%) in a hydrogenous environment did not cause a formation of a protective surface layer which could decrease surface conductivity of the material.

The YSZ-NiO anode ceramics, depending on a content of hydrogen in a gaseous atmosphere, displayed quite different mechanical behavior as compared to porous $\mathrm{Ni}$ (Figure 1). Based on previously obtained data [5,7], it was stated that after a single exposure of the $\mathrm{YSZ}-\mathrm{NiO}$ ceramics

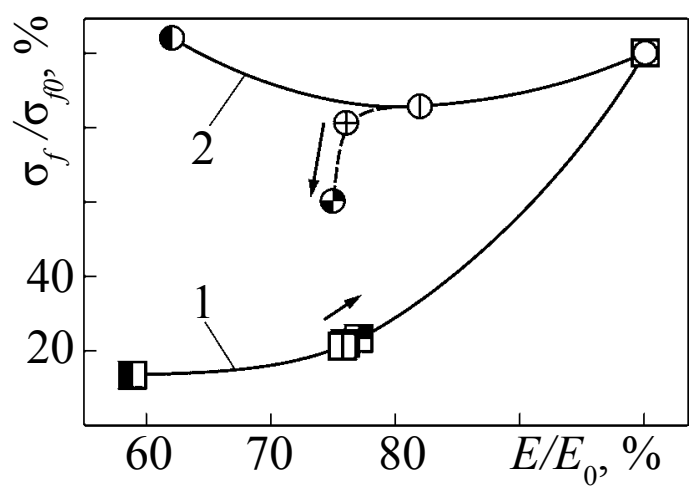

Figure 2: Dependencies of the relative strength on the relative stiffness for porous $\mathrm{Ni}$ (curve 1) and YSZ-Ni cermet (2). Legends (corresponding modes in Table 1): square symbols correspond to porous $\mathrm{Ni}$ and round ones to YSZ-Ni cermet; $\square$ (1), $\bigcirc$ (6) as-received materials; Ш (2), (1) (7) processing in Ar-5 vol\% $\mathrm{H}_{2}$ at $600{ }^{\circ} \mathrm{C}$ for $4 \mathrm{~h} ; \mathbf{\square}(3)$, $\mathbf{D}(8)$ processing in 99.99 vol\% $\mathrm{H}_{2}$ at $600{ }^{\circ} \mathrm{C}$ for $4 \mathrm{~h}$; $\boxplus(4), \bigoplus$ (9) processing in $\mathrm{Ar}-5 \mathrm{vol} \% \mathrm{H}_{2}$ at $600{ }^{\circ} \mathrm{C}$ for $4 \mathrm{~h}$, aging in Ar-5 vol\% $\mathrm{H}_{2}$ with 7 vol\% $\mathrm{H}_{2} \mathrm{~S}^{2}$ at $600{ }^{\circ} \mathrm{C}$ for $4 \mathrm{~h}$; $(5), \boldsymbol{\theta}$ (10) processing in $\mathrm{Ar}-5$ vol\% $\mathrm{H}_{2}$ at $600{ }^{\circ} \mathrm{C}$ for $4 \mathrm{~h}$, aging in Ar-5 vol\% $\mathrm{H}_{2}$ with 18 vol $\% \mathrm{H}_{2} \mathrm{~S}$ at $600{ }^{\circ} \mathrm{C}$ for $4 \mathrm{~h}$. The arrows show the tendencies of change of the characteristics while hydrogen sulfide content increases. in Ar-5 vol\% $\mathrm{H}_{2}$ gas mixture, only the surface layers of the particles of nickel oxide are reduced, and after exposure in hydrogen, the particles are reduced completely what causes the substantial growth of electrical conductivity of the material (up to $(1.4-1.7) \cdot 10^{5} \mathrm{~S} / \mathrm{m}$ at $600^{\circ} \mathrm{C}$ ).

As a result of complete reduction of the nickel phase in pure hydrogen followed by a significant plasticization of reduced $\mathrm{Ni}$, the relative stiffness decreased to $62 \%$.

The local EDX analysis (with dispersion of energy, $\mathrm{W}$ ) of the zirconium and nickel phases of the YSZ-Ni cermet after aging in hydrogenous atmospheres containing 7 and 18 vol $\% \mathrm{H}_{2} \mathrm{~S}$ did not detect sulfur in both these phases and within their boundaries (see spectra No. 1-6 in Table 2 and Table 3). However, during the EDX analysis of entire areas on the cross section surfaces of the aged specimens, from 0.12 to $0.27 \mathrm{wt} \%$ sulfur was found (see Table 2 and Table 3). In the core of all specimens its content did not exceed $0.12 \mathrm{wt} \%$.

However, in near-surface layers (see Table 2 and Table 3), the sulfur content depended on the concentration of hydrogen sulfide admixture and was, respectively, 0.14 wt $\%$ (at a concentration of $7 \mathrm{vol} \% \mathrm{H}_{2} \mathrm{~S}$ ) and $0.27 \mathrm{wt} \%(18$ vol $\left.\% \mathrm{H}_{2} \mathrm{~S}\right)$.

On the basis of microstructural analysis of the YSZ$\mathrm{Ni}$ cermet specimens after aging in hydrogenous atmospheres containing 7 and 18 vol\% $\mathrm{H}_{2} \mathrm{~S}$, certain features of changes in their structure and fracture micromechanisms were revealed (Figure 3). Taking into account the above-mentioned peculiarities of the distribution of sulfur in the volume of treated samples and its insignificant content, even in near-surface layers of specimens,

Table 2: The data of the EDX spectra of the YSZ-Ni cermet specimen after aging in $\mathrm{Ar}-5 \mathrm{vol} \% \mathrm{H}_{2}$ gas atmosphere with an admixture of $7 \mathrm{vol} \% \mathrm{H}_{2} \mathrm{~S}$.

\begin{tabular}{|c|c|c|c|c|c|c|c|c|c|c|}
\hline \multirow{2}{*}{$\begin{array}{l}\text { Chemical } \\
\text { element and } \\
\text { X-ray series }\end{array}$} & \multicolumn{2}{|c|}{$\begin{array}{l}\text { Spectrum } 1 \\
\text { (Ni-phase) }\end{array}$} & \multicolumn{2}{|c|}{$\begin{array}{l}\text { Spectrum } 2 \\
\text { (Zr-phase) }\end{array}$} & \multicolumn{2}{|c|}{$\begin{array}{l}\text { Spectrum } 3 \\
\text { (boundary) }\end{array}$} & \multicolumn{2}{|c|}{$\begin{array}{l}\text { Specimen surface } \\
\text { layer }\end{array}$} & \multicolumn{2}{|c|}{ Specimen core } \\
\hline & wt $\%$ & at $\%$ & wt $\%$ & at $\%$ & wt $\%$ & at $\%$ & $w t \%$ & at $\%$ & wt $\%$ & at $\%$ \\
\hline $\mathrm{OK}$ & 25.62 & 55.82 & 28.06 & 68.39 & 24.09 & 60.63 & 19.20 & 51.04 & 14.41 & 42.71 \\
\hline SK & - & - & - & - & - & - & 0.14 & 0.18 & 0.12 & 0.18 \\
\hline $\mathrm{Ni} \mathrm{K}$ & 74.38 & 44.18 & 3.25 & 2.15 & 23.67 & 16.24 & 43.08 & 31.21 & 43.88 & 35.43 \\
\hline Y L & - & - & 8.29 & 3.64 & 5.75 & 2.61 & 3.92 & 1.88 & 4.50 & 2.40 \\
\hline Zr L & - & - & 60.40 & 25.82 & 46.49 & 20.52 & 33.66 & 15.69 & 37.09 & 19.28 \\
\hline
\end{tabular}

Table 3: The data of the EDX spectra of the YSZ-Ni cermet specimen after aging in Ar-5 vol\% $\mathrm{H}_{2}$ gas atmosphere with an admixture of 18 vol\% $\mathrm{H}_{2} \mathrm{~S}$.

\begin{tabular}{|c|c|c|c|c|c|c|c|c|c|c|}
\hline \multirow{2}{*}{$\begin{array}{l}\text { Chemical } \\
\text { element and } \\
\text { X-ray series }\end{array}$} & \multicolumn{2}{|c|}{$\begin{array}{l}\text { Spectrum } 4 \\
\text { (Ni-phase) }\end{array}$} & \multicolumn{2}{|c|}{$\begin{array}{l}\text { Spectrum } 5 \\
\text { (Zr-phase) }\end{array}$} & \multicolumn{2}{|c|}{$\begin{array}{l}\text { Spectrum } 6 \\
\text { (boundary) }\end{array}$} & \multicolumn{2}{|c|}{$\begin{array}{l}\text { Specimen surface } \\
\text { layer }\end{array}$} & \multicolumn{2}{|c|}{ Specimen core } \\
\hline & wt \% & at $\%$ & wt $\%$ & at $\%$ & wt $\%$ & at $\%$ & wt $\%$ & at $\%$ & wt $\%$ & at $\%$ \\
\hline $\mathrm{OK}$ & 25.96 & 56.26 & 28.71 & 69.11 & 26.02 & 64.35 & 17.14 & 47.53 & 14.49 & 42.82 \\
\hline S K & - & - & - & - & - & - & 0.27 & 0.37 & 0.12 & 0.18 \\
\hline $\mathrm{NiK}$ & 74.04 & 43.74 & 3.03 & 1.99 & 20.33 & 11.36 & 44.15 & 33.36 & 44.24 & 35.62 \\
\hline Y L & - & - & 7.99 & 3.46 & 6.81 & 3.24 & 4.07 & 2.03 & 4.24 & 2.25 \\
\hline Zr L & - & - & 60.27 & 25.44 & 46.84 & 21.05 & 34.37 & 16.71 & 36.91 & 19.13 \\
\hline
\end{tabular}


Citation: Vasyliv B, Podhurska V, Ostash O, et al. (2018) Influence of Hydrogen Sulfide Containing Atmospheres on the Physical and Mechanical Properties of Solid Oxide Fuel Cell Anode Materials. Insights Agric Technol 1(1):1-6
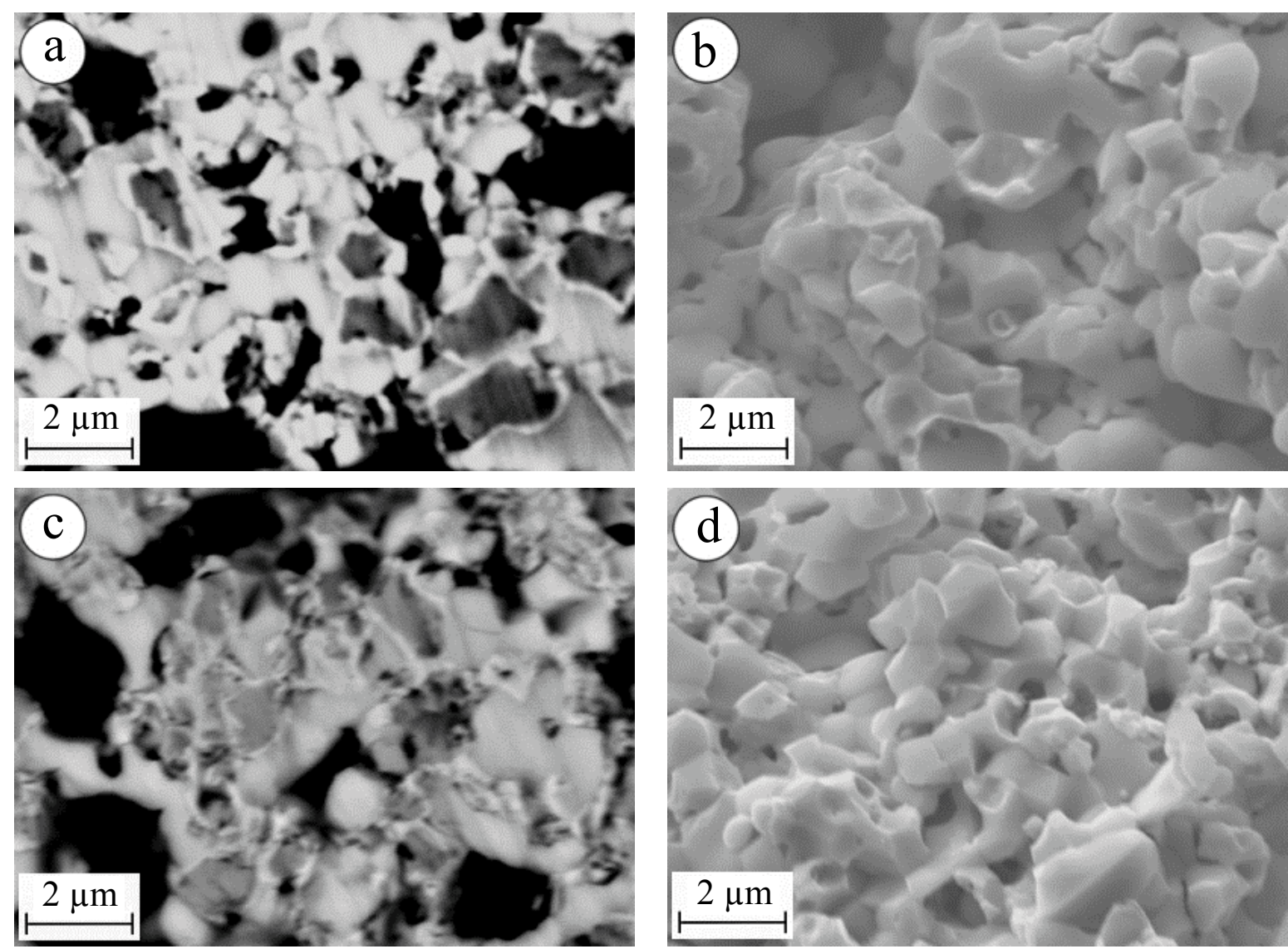

Figure 3: SEM images of the microstructures (a,c) and microfractograms (b,d) of YSZ-Ni cermet specimens after aging in Ar-5 vol\% $\mathrm{H}_{2}$ gas atmosphere with an admixture of 7 vol\% $\mathrm{H}_{2} \mathrm{~S}(\mathrm{a}, \mathrm{b})$ and $18 \mathrm{vol} \% \mathrm{H}_{2} \mathrm{~S}(\mathrm{c}, \mathrm{d})$.

it can be assumed that the material degrades mainly due to the action of high-temperature $\mathrm{H}_{2} \mathrm{~S}$ gas, which reacts with reduced nickel. The observed tendency to reduce the amount of oxygen in the near-surface layers indicates that hydrogen sulfide, at its high concentration, improves the reduction of the nickel phase. It is likely that both of these processes (more active reduction and interaction of nickel with high-temperature hydrogen sulfide gas) occur mainly on the three-phase boundaries (pores-nickel phase-zirconium phase), resulting in the concentration of sulfur as a product of the reaction in these places, i.e., in the pores and near them.

First of all, the degradation of the structure is manifested through the discontinuity of the "zirconium phase-nickel phase" and "nickel phase-nickel phase" bonds. This does not violate the integrity of the YSZ ceramic skeleton in the cermet at concentrations up to $7 \mathrm{vol} \% \mathrm{H}_{2} \mathrm{~S}$. With the increase of the hydrogen sulfide concentration followed by the improvement of the nickel phase reduction, larger amount of completely reduced small nickel particles is formed (Figure $3 \mathrm{c}$ as compared to Figure 3a). These particles interact actively with hydrogen sulfide and weaken their bonds with the particles of the zirconium phase. Such structural transformations are followed by a change of fracture micromechanisms prevailing in a cermet: from the mixed one containing both the elements of the cleavage and intergranular fracture along the cracked boundaries (Figure $3 \mathrm{~b}$ ) to completely intergranular fracture (Figure $3 \mathrm{~d}$ ). As a result, the cermet strength is reduced to $61 \%$ of the initial state (Table 1).

The arrow along the deviated branch of curve 2 (see Figure 2) indicates a general tendency of change of the relative strength and stiffness of the YSZ-Ni anode cermet while hydrogen sulfide content in high-temperature hydrogenous atmosphere increases. It can be marked that the arrow direction differs from that for porous $\mathrm{Ni}$.

Unlike mechanical behavior, the electrical conductivity of YSZ-Ni cermet after aging for $4 \mathrm{~h}$ at $600{ }^{\circ} \mathrm{C}$ in a hydrogenous atmosphere at a concentration of 7 and 18 vol\% $\mathrm{H}_{2} \mathrm{~S}$ is $(5.5-6.0) \cdot 10^{4} \mathrm{~S} / \mathrm{m}$ at $600{ }^{\circ} \mathrm{C}$, which does not differ from the value for one-time reduced cermet ( $\mathrm{Ta}$ ble 1). The high-temperature hydrogenous atmosphere with an admixture of $7 \mathrm{vol} \% \mathrm{H}_{2} \mathrm{~S}$ has a little effect on the conductivity and strength of the YSZ-Ni anode material. The little drop of the relative stiffness (see Figure 2) is probably connected with a slight improvement of the reduction of the nickel phase by hydrogen sulfide, as compared to pure Ar-5 vol\% $\mathrm{H}_{2}$ atmosphere. This concentration of hydrogen sulfide in the SOFC operating 
Citation: Vasyliv B, Podhurska V, Ostash O, et al. (2018) Influence of Hydrogen Sulfide Containing Atmospheres on the Physical and Mechanical Properties of Solid Oxide Fuel Cell Anode Materials. Insights Agric Technol 1(1):1-6

environment does not lead to a significant decrease in its strength.

\section{Conclusions}

Exposition of porous nickel for $4 \mathrm{~h}$ in a hydrogenous atmosphere at the temperature $600{ }^{\circ} \mathrm{C}$ causes its significant plasticization. The relative strength and stiffness of the material decrease with increasing hydrogen concentration and can reach 13.9 and 59\% respectively after the treatment in pure hydrogen. Neither 7 nor 18 vol\% $\mathrm{H}_{2} \mathrm{~S}$ in a hydrogenous atmosphere affects plasticity, strength, and electrical conductivity of the material.

The hydrogenous atmosphere containing up to 7 vol\% $\mathrm{H}_{2} \mathrm{~S}$ has a little effect on the strength and electrical conductivity of the YSZ-Ni cermet when aging for $4 \mathrm{~h}$ at $600{ }^{\circ} \mathrm{C}$. Increased content of $\mathrm{H}_{2} \mathrm{~S}(18 \mathrm{vol} \%)$ causes some changes in the YSZ-Ni cermet structure due to improvement of the reduction process and formation of a large number of fully reduced tiny nickel particles which react with hydrogen sulfide. Sulfur is segregated on the boundaries between the zirconia and nickel phases and pores. Finally, multiple breaking of the zirconia-nickel bonds occurs that results in reduced strength of the cermet (by $39 \%$ as compared to as-received YSZ-NiO ceramics).

\section{References}

1. Sarantaridis D, Atkinson A (2007) Redox cycling of Nibased solid oxide fuel cell anodes: A Review. Fuel Cells 3: 246-258.

2. Ettler M, Timmermann H, Malzbender J, et al. (2010) Durability of $\mathrm{Ni}$ anodes during reoxidation cycles. Journal of Power Sources 195: 5452-5467.
3. Vasyliv BD (2009) A procedure for the investigation of mechanical and physical properties of ceramics under the conditions of biaxial bending of a disk specimen according to the ring-ring scheme. Materials Science 45: 571-575.

4. Vasyliv BD, Ostash OP, Podhurs'ka VYa, et al. (2013) Method of treatment of NiO-Containing anodes of a solid oxide fuel cell.

5. Vasyliv BD, Podhurs'ka VYa, Ostash OP, et al. (2013) Influence of reducing and oxidizing media on the physicomechanical properties of ScCeSZ-NiO and YSZ-NiO ceramics. Materials Science 49: 135-144.

6. Podhurs'ka VY, Vasyliv BD, Ostash OP, et al. (2014) Structural transformations in the NiO-Containing anode of ceramic fuel cells in the course of its reduction and oxidation. Materials Science 49: 805-811.

7. Podhurska V, Vasyliv B, Ostash O, et al. (2016) Influence of treatment temperature on microstructure and properties of YSZ-NiO anode materials. Nanoscale Res Lett 11: 93.

8. Alstrup I, Rostrup-Nielsen JR, Roen S (1981) High temperature hydrogen sulfide chemisorption on nickel catalysts. Applied Catalysis 1: 303-314.

9. Twigg MV (1996) Catalyst Handbook. (2 ${ }^{\text {nd }}$ edn), Manson Publishing Ltd, London.

10. Primdahl S (1999) Nickel/Yttria-stabilised zirconia cermet anodes for solid oxide fuel cells.

11. Norheim A, Wærnhus I, Broström M, et al. (2007) Experimental Studies on the Influence of $\mathrm{H} 2 \mathrm{~S}$ on Solid Oxide Fuel Cell Performance at $800{ }^{\circ} \mathrm{C}$. Energy Fuels 21: 1098-1101.

12. Dees DW, Balachandran U, Dorris SE, et al. (1989) Interfacial effects in monolithic solid oxide fuel cells. SOFC I: The Electrochemical Society Proceedings Series. Pennington, NJ, 317-321.

13. Van der Pauw LJ (1958) A Method of measuring specific resistivity and hall effect of discs of arbitrary shape. Philips Research Reports 13: 1-9. 